\title{
ヘリコバクター・ピロリによる発癌機構
}

\author{
畠山昌則

\section{Oncogenic mechanism of Helicobacter pylori} \\ Masanori HatakeYama, M.D., Ph.D. \\ Division of Molecular Oncology, Institute for Genetic Medicine, Hokkaido University
}

(Received April 4, 2008)

\begin{abstract}
summary
On a global scale, gastric carcinoma is the second leading course of the cancer-related deaths. Recent studies have provided evidence that cagA-positive Helicobacter pylori plays a causal role for the development of gastric carcinoma. The $\operatorname{cag} A$-encoded CagA protein is delivered into $H$. pylori-attached gastric epithelial cells via the bacterial type IV secretion system (TFSS). Delivered CagA undergoes tyrosine phosphorylation by Src family kinases at the conserved EPIYA motifs and then specifically binds and deregulates SHP-2 tyrosine phosphatase, a bona fide oncoprotein involved in human malignaicies. As a result, CagA causes aberrant mitogenic signal as well as elevated cell motility in gastric epithelial cells. Also, CagA specifically interacts with and inhibits PAR1b/MARK2 polarity-regulating kinase to disrupt tight junctions and cause loss of epithelial apical-basolateral cell polarity. These CagA activities have been suspected to play an important role in gastric carcinogenesis. Indeed, recently generated $c a g A$-transgenic mice expressing CagA systemically developed gastrointestinal carcinomas as well hematopoietic malignancies such as myeloid leukemia and B-cell lymphoma. The observations collectively indicate that $H$. pylori CagA is the first identified bacterial oncoprotein in volved in gastric carcinogenesis.
\end{abstract}

Key words_-Helicobacter pylori; CagA; SHP-2; PAR1b; oncoprotein

\section{抄 録}

胃癌は全世界人口に抢ける部位別癌死亡の第二位を占める。近年の研究から， $\operatorname{cag} A$ 遺伝子を保有するへリコバ クター・ピロリ（ピロリ菌）の持続感染が胃癌発症に決定的な役割を担うことが明らかになってきた. cag $A$ 遺伝 子産物である CagA タンパク質はピロリ菌が保有するミクロの注射針（IV 型分泌機構）を通して菌体内から胃上 皮細胞内へと直接注入される. 細胞内に侵入した CagA は SHP-2 癌タンパク質に代表される細胞内シグナル伝達 分子と特異的に結合しそれらの機能を脱制御することにより，細胞増殖・細胞運動にかかわる多彩な細胞内シグナ ル伝達系を撹乱する．同時に，CagA は上皮細胞の極性制御を担うPAR1b/MARK2 キナーゼと結合し不活化する 結果，消化管粘膜構築を崩壊させる. 一連のこうした生物活性から，CagA は胃癌発症に深くかかわることが推察 されてきた．ごく最近，ピロリ菌 CagA を全身性に発現するトランスジェニックマウスにおいて胃癌，小腸癌さら には骨髄性白血病，B 細胞リンパ腫が発症することが明らかとなり，CagA が生体内で直接の発癌活性を示す細菌 由来の初の癌タンパク質（bacterial oncoprotein）であることが示された.

\section{はじめに}

胃癌は全世界における部位別癌死亡の第二位を占 め，毎年約 50 万人が胃癌で命を落としていると推 定されている. 胃癌の大多数を占める腺癌は病理組 織学的に分化型（腸型；intestinal type）と未分化 型（びまん型; diffuse type）に大別される.未分 化型胃癌の一部は家族性に発生し，その原因遺伝子

北海道大学遺伝子病制御研究所 ·分子腫瘍分野
としてE-cadherin が同定されている1). しかしな がら, 胃癌に共通する特徵的な遺伝子変異は知られ ておらず，胃癌発症の分子機構は未だに十分解明さ れていない。こうした中, 最近の大規模疫学調査か ら, 分化型, 未分化型を問わず胃腺癌発症にへリコ バクター・ピロリ（ピロリ菌）の持続感染が重要な 役割を担うことが明らかになってきた2). 加えて， ピロリ菌感染は B リンパ球を起源とする胃 MALT (mucosa-asssociated lymphid tussue) リンパ腫発症 にも深くかかわる3). ピロリ菌は Marshall と War- 
renによりヒト胃粘膜から単離されたらせん状グラ 么陰性桿菌であり ${ }^{4)}$, 全世界人口の約半数に感染し ていると考えられている，本稿では，ピロリ菌が保 有する癌タンパク質 CagAの機能を通してその発癌 メカニズムを考察したい.

\section{I. ピロリ菌 CagA と cag pathogenicity island (cag PAI)}

ピロリ菌は CagA（Cytotoxin-associated gene A antigen）タンパク質産生能の有無により二群に大 別される。CagA をコードする $\operatorname{cag} A$ 遺伝子は，cag pathogenicity island (cag PAI) とよばれる約 40 キ ロベースのピロリ菌ゲノム内 DNA 領域に存在する (図 1 $)^{5,6)}$.cag PAI は水平伝播によりピロリ菌ゲノ ム内に挿入された起源不明の外来 DNA 断片である. cag PAI 内には約 30 個の遺伝子が存在し, その多 くは IV 型分泌機構と呼ばれるミクロの注射針様装 置を構成する一連の蛋白群をコードする（図 2). $\operatorname{cag} A$ 陽性ピロリ菌（=cag PAI 陽性ピロリ菌）は $\operatorname{cag} A$ 陰性ピロリ菌感染に比べてはるかに激しい胃 粘膜病変を惹起し, 疫学的にも胃癌発症と強く相関 する ${ }^{7,8)}$.

\section{II. ピロリ菌 CagA の胃上皮細胞内移行と チロシンリン酸化}

胃に生息するピロリ菌の多くは胃粘液内に浮遊し て存在するが，一部（10２0\%程度）は胃上皮細胞 表面に直接付着する，胃上皮細胞に接触したピロリ 菌は cag PAIによりコードされる IV 型分泌機構を 用いて, CagA を胃上皮細胞内へ直接注入する（図 $2)^{9)}$. 注入された CagA は細胞膜内面に移行すると ともに Srcファミリーキナーゼによりチロシンリン 酸化される ${ }^{10,11)}$.

$\mathrm{CagA}$ タンパク質の $\mathrm{C}$ 末側領域内には $\mathrm{Glu}-\mathrm{Pro}^{-}$ Ile-Tyr-Ala（EPIYA）モチーフと呼ばれる特徵的 な配列が複数出現し，このモチーフ内のチロシン残 基が Src キナーゼによりリン酸化される. 各々の EPIYA モチーフの周辺を構成するアミノ酸配列を もとに, CagA の EPIYA 領域を構成する 4 つの 異なるEPIYA 含有アミノ酸セグメント（EPIYA

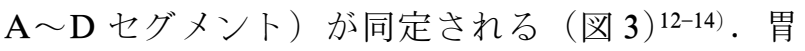
癌の比較的少ない欧米諸国で単離されるピロリ菌が 保有する CagA（欧米型 CagA）の EPIYA 領域は, 32 アミノ酸からなる EPIYA-A セグメント，40ア ミノ酸からなるEPIYA-B セグメントならびに 34 アミノ酸からなる EPIYA-C セグメントから構成さ

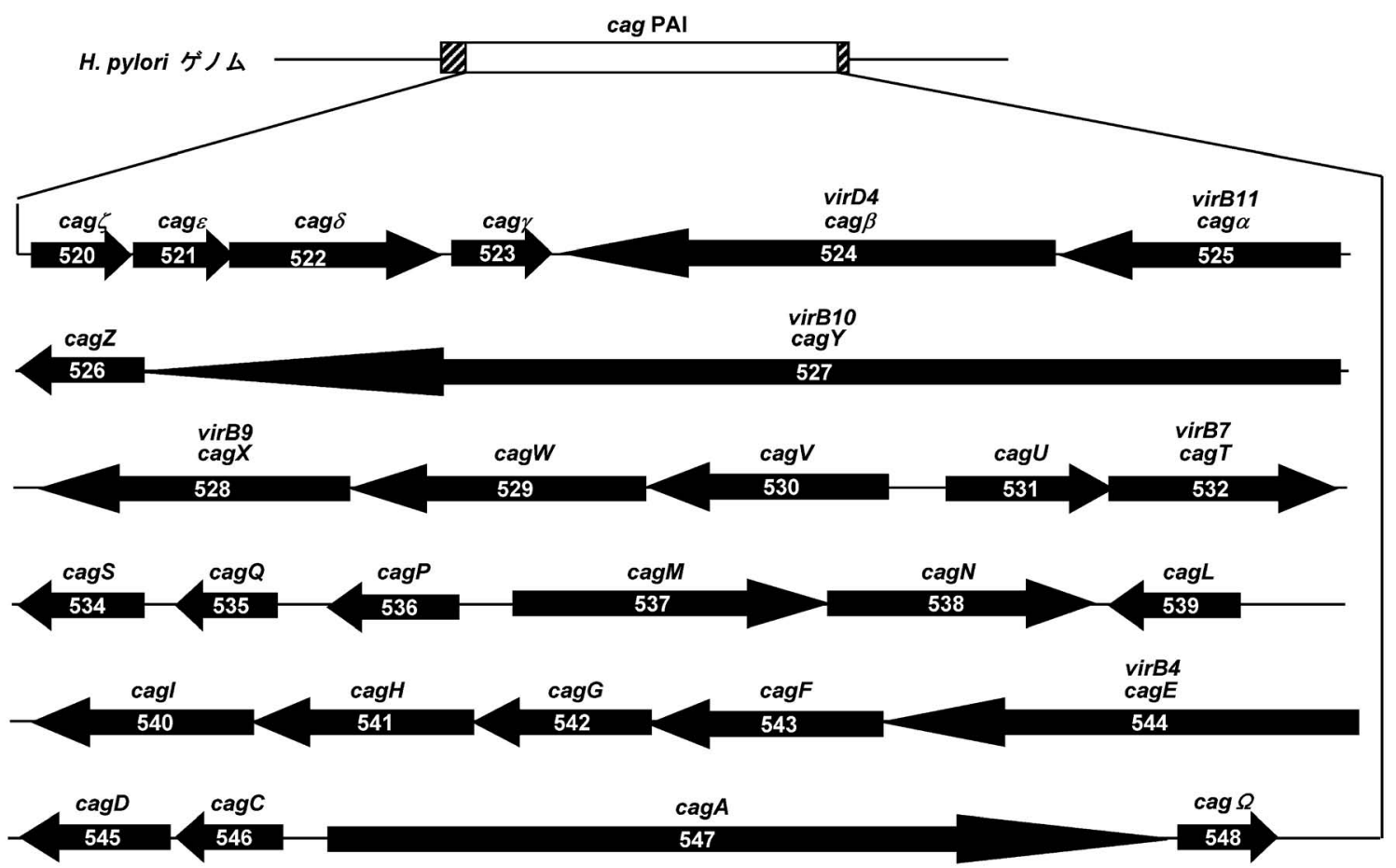

図 1 ピロリ菌 cag PAI を構成する遺伝子群

ピロリ菌 26695 標準株が保有する cag PAI の構造を示す。cag PAI はピロリ菌ゲノム中の glutamate racemase 遺伝子内に挿入 されている. 矢印は遺伝子の転写方向を示す。 


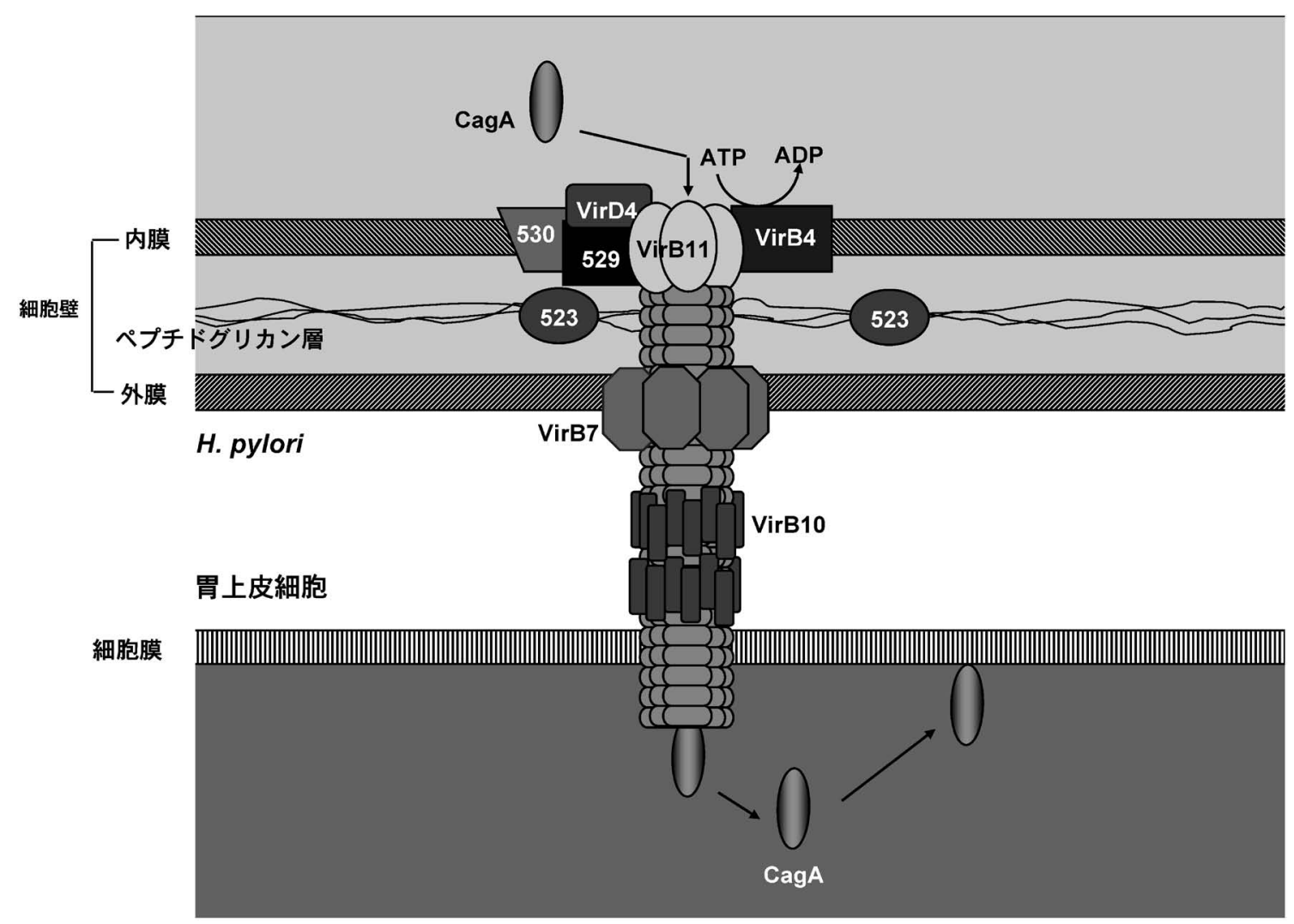

図 2 ピロリ菌 IV 型分泌機構を介する CagA の胃上皮細胞内侵入

cag PAI にコードされる蛋白群は集合してミクロの注射針様装置（IV 型分泌機構）を構築する. CagA は胃上皮細胞に突き刺 された IV 型分泌機構の内部を通り，ピロリ菌菌体側から胃上皮細胞の細胞質内に移行する.

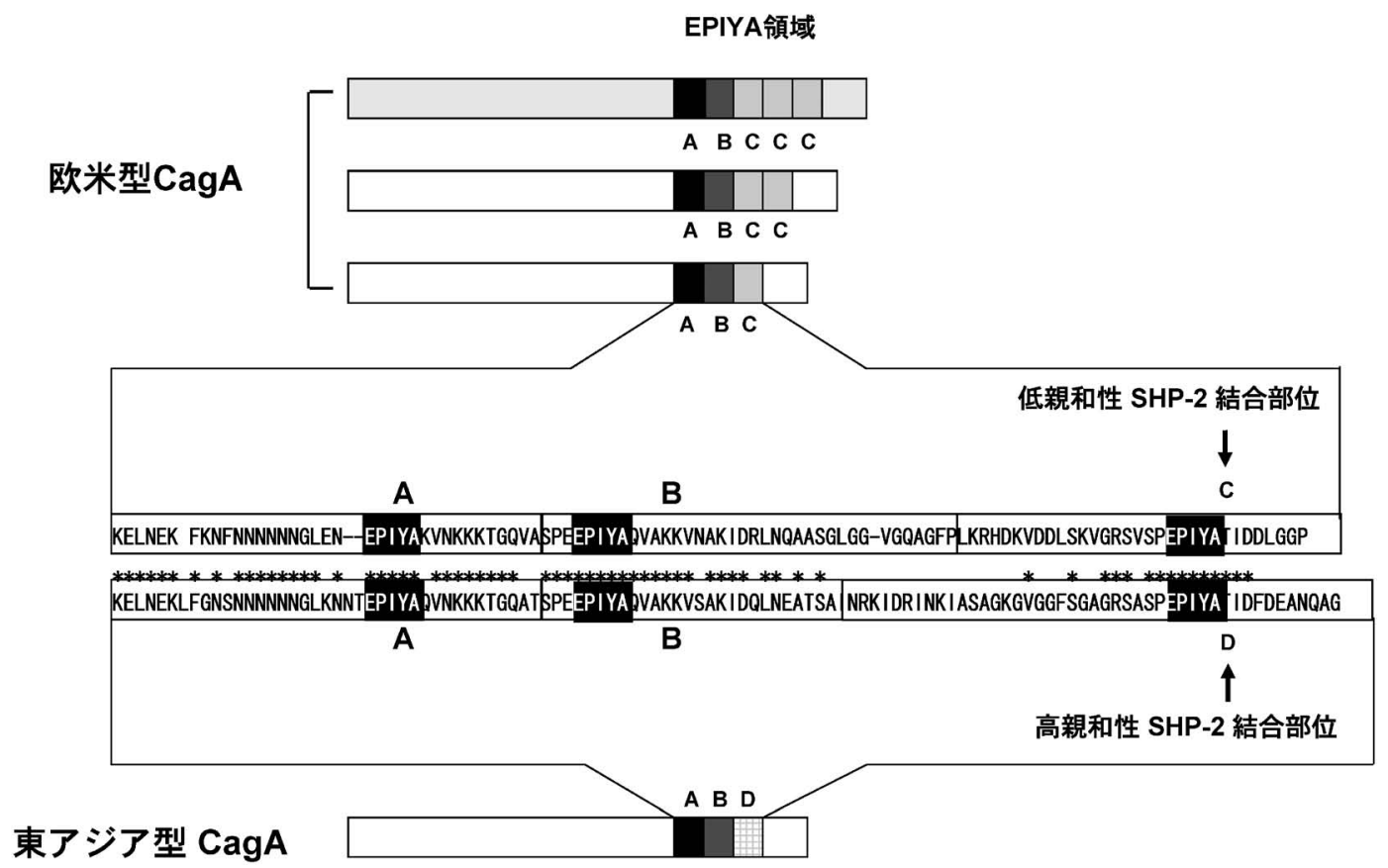

図 3 CagA の EPIYA 領域に存在する構造多型と各 EPIYA セグメントの構成

欧米型 CagA は EPIYA-A セグメント, EPIYA-B セグメントならびにEPIYA-C セグメントから構成される EPIYA 領域を保 有する. ABC 型がもっとも一般的であるが，一部の CagA では EPIYA-C セグメントが直列増幅する. 欧米型 CagA は EPIYAA セグメント，EPIYA-B セグメントならびに EPIYA-D セグメントから構成される EPIYA 領域を保有する. 
れる、EPIYA-C セグメントは単離される欧米型 $\mathrm{CagA}$ 分子種間に扮いてその数が $1 \sim 3$ 個の間で変 動する (多くの場合 1 個)。これは, EPIYA-C セ グメントをコードする 102 ベースペアからなる $\operatorname{cag} A$ 遺伝子領域がゲノム DNA 複製時の相同組み 換えにより容易に重複, 欠失結果と考えられる。こ れに対し日本，韓国など高頻度に胃癌が発症する東 アジア諸国で単離されるピロリ菌由来の CagA（東 アジア型 CagA）が保有する EPIYA 領域は, EPIYA-A セグメント，EPIYA-B ならびに東アジ ア型 CagA 特異的な EPIYA-D セグメントから構 成される.

\section{CagA の細胞内標的としての SHP-2}

$\mathrm{Src}$ によりチロシンリン酸化された CagA は $\mathrm{N}$ 末 側に 2 つの SH2 ドメインを保有するチロシンホス ファターゼ SHP-2 と特異的に結合する (図 4) ${ }^{10,12)}$. SHP-2 との複合体形成にはチロシンリン酸化され た CagA の EPIYA-C セグメント（欧米型 CagAの 場合）ないし EPIYA-D セグメント（東アジア型 CagA の場合）が関与する。 また SHP-2 が有する
2 つの SH2 ドメインのどちらか一方の機能を欠失 させると CagA との結合活性は消失する．SHP-2 は単独で存在する場合, $\mathrm{N}$ 末側の $\mathrm{SH} 2$ ドメインが ホスファターゼドメインと分子内相互作用するた め, そのホスファターゼ活性は不活化された状態で 維持される．この不活化型にある SHP-2 の SH2 ド メインにチロシンリン酸化タンパクが結合すること により，抑制性の分子内相互作用が解除されホスフ アターゼドメインが活性化される. 事実, チロシン リン酸化 CagA との結合により, SHP-2 のチロシ ンホスファターゼ活性は著しく増強する。

胃上皮細胞に CagA を発現させると, 著しい細胞 質伸長で特徵づけられるユニークな細胞形態変化が 誘導される.八チドリのくちばしに似たこの形態変 化はハミングバード (hummingbird) 表現型と呼ば れる9). CagA によるハミングバード表現型の誘導 には CagA のチロシンリン酸化ならびにその後の SHP-2 活性化が重要な役割を担う。CagAにより 活性化された SHP-2の基質分子として細胞接着斑 キナーゼ FAK が同定されている15)。SHP2 は脱リ ン酸化を介して FAK のキナーゼ活性を抑制し, 細

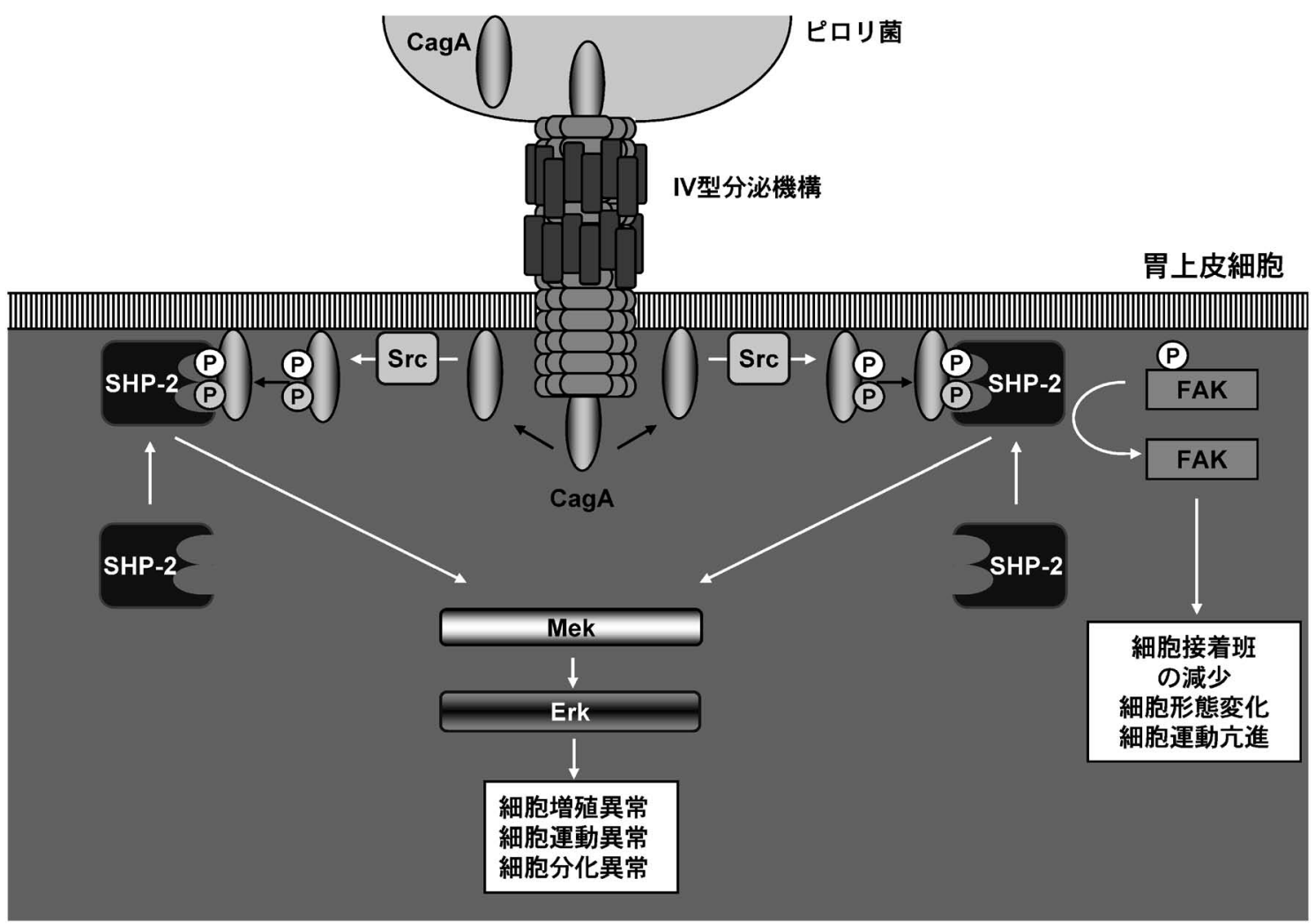

図 4 CagA による細胞内シグナル伝達の撹乱

胃上皮細胞に侵入後, Srcによりチロシンリン酸化された CagA は癌タンパク質として知られる SHP-2 チロシンホスファター ゼと特異的に結合し，そのホスファターゼ活性を異常にえ進する. CagAにより異常活性化された SHP-2 情 FAKを脱リン酸化 することにより細胞運動性を亢進させるとともに，Erk MAP キナーゼの持続的活性化による異常な細胞増殖シグナルを生成する. 
胞接着斑の生成を阻害することにより細胞一基質相 互作用を低下させる。この CagA-SHP-2-FAK 経 路活性化がハミングバード表現型の誘導ならびに細 胞運動性元進に重要な役割を担うと考えられている (図 4).ささらに，SHP-2 はRas 依存的ならびに Ras 非依存的に Erk MAP キナーゼ活性を増強し細 胞増殖を促す事が知られている．CagA を異所性発 現する胃上皮細胞においても SHP-2 依存的な Erk MAP キナーゼの持続活性化 (sustained activation) が認められる16). Erk の持続活性化は細胞周期の G1 期-S 期移行に必須であり, CagA は SHP-2 依 存的に Erk を持続活性化し異常な細胞増殖シグナ ルを誘起することを示している（図 4).

東アジア型 CagA は EPIYA-D セグメントを介 して，また欧米型 CagA は EPIYA-C セグメントを 介して SHP-2 と結合する. SHP-2 の SH2 ドメイ ンと高親和性結合を示すリン酸化ペプチドのコンセ ンサス配列は $\mathrm{pY}-(\mathrm{V} / \mathrm{T} / \mathrm{A} / \mathrm{I} / \mathrm{S})-\mathrm{X}-(\mathrm{L} / \mathrm{I} / \mathrm{V})-\mathrm{X}-(\mathrm{F}$ /W）（pY はリン酸化チロシン，Xは任意のアミ） 酸）で表される. EPIYA-C セグメントの pY + 5 位 はアスパラギン酸（D）でありコンセンサス配列の フェニルアラニン $(\mathrm{F})$ ないしトリプトファン $(\mathrm{W})$ とは異なる。これに対し，EPIYA-D セグメントの $\mathrm{pY}+5$ 位はフェニルアラニンであり，コンセンサ 又配列と完全に一致する。事実, EPIYA-D セグメ ントを有する東アジア型 CagA は EPIYA-C セグメ ントを有する欧米型 CagA に比べてはるかに強く SHP-2 と結合し，より強いハミングバード表現型 の誘導活性を発揮する ${ }^{12,14)}$ 。この活性差は上述した 両セグメント間の $\mathrm{pY}+5$ 位の一アミノ酸の違いに
起因する（図 5). また, EPIYA-C セグメントの数 が変動する欧米型 CagA では, EPIYA-C セグメン トの数に比例して SHP-2 結合能ならびにハミング バード細胞誘導活性が増大する（図 6).

SHP-2 は消化管上皮細胞を含む多くの体細胞に 構成的に発現する. 一般にホスファターゼはシグナ ル抑制分子として働くが，上述したごとく, SHP2 は増殖因子受容体と Ras-MAP キナーゼ経路をつ なぐ正のシグナル伝達分子として機能するとともに 細胞の形態 ·運動能充進にも深くかかわる ${ }^{17)}$. 最 近, 低伸長 - 特徵的顔貌 - 先天性心疾患 - 精神発育 遅滞で特徵づけられる Noonan 症候群において, SHP-2 をコードするPTPN11 遺伝子の生殖系細胞 点突然変異が明らかにされた ${ }^{18)}$ 。一連の変異は機能 獲得型（gain-of-function mutation）変異であり, 変異 SHP-2 のホスファターゼ活性は増強している.

Noonan 症候群患者では白血病や神経芽細胞腫とい った悪性腫瘍が合併する. その後の研究から, 散発 性の小児骨髄単球系白血病 (juvenile myleomonocytic leukemina), 骨髄異型症候群, B 細胞急性リ ンパ性白血病, 急性骨髄性白血病ならびに神経芽細 胞腫においてPTPN11 の機能獲得型変異が見いだ された ${ }^{19,20)}$.したがって SHP-2 はRas と同様，そ の脱制御がヒト癌の発症に直接関与する癌タンパク 質であり，CagA による SHP-2の脱制御と細胞癌 化との関連が強く示唆される.

\section{CagA による上皮粘膜構築の破壊機構}

消化管粘膜を構成する上皮細胞は, タイトジャン クション (tight junction) と呼ばれる特異的なベル

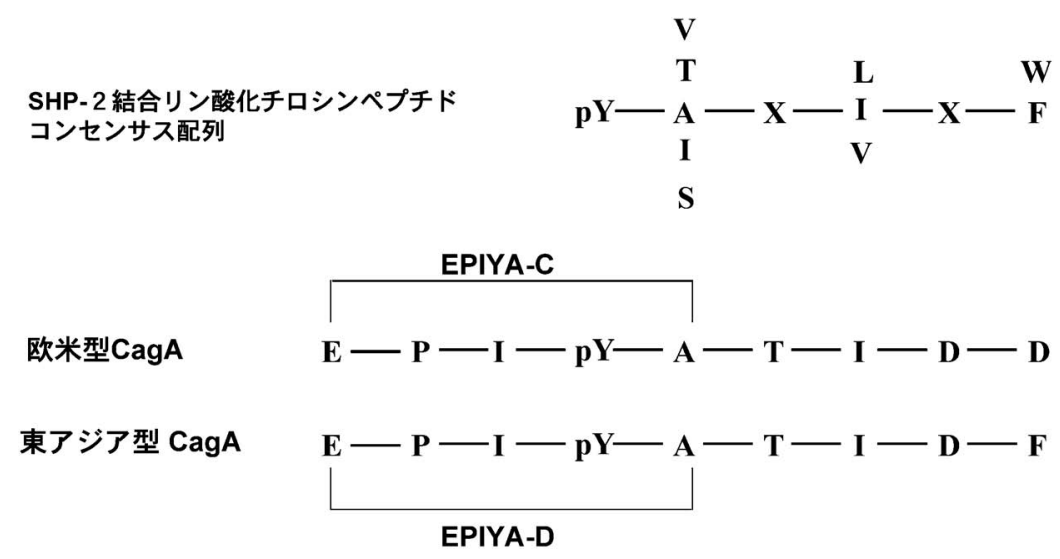

図 5 SHP-2 結合親和性と東アジア型ならびに欧米型 CagA

欧米型 CagA の EPIYA-C セグメントアミノ酸と東アジア型 CagA の EPIYA-D セグメントアミノ酸. 東アジア型 CagA はリ ン酸化チロシン $(\mathrm{pY})$ から下流 5 番目のアミノ酸がフェニルアラニン $(\mathrm{F})$ となっており, SHP-2 の高親和性ペプチドコンセン サス配列と一致するのに対し, 欧米型 CagAの（pY+5）位はアスパラギン酸（D）でありコンセンサス配列と一致しない. 
ト状の細胞間接着構造を介して隣接の細胞と緊密に 繋がり合い，一層の敷石状構造を形成する. 各々の 上皮細胞の細胞膜面は, タイトジャンクションを境 界に頂端側（apical side）と基底側（basal side）に 分割される．頂端側は食物などが通過する管腔に向 き, 基底側は生体内部の血管や結合組織・筋肉に接 することから，各細胞膜面の機能的役割は必然的に 異なる、極性化（polarization）と呼ばれる細胞膜 各面の機能の非対称化はタイトジャンクションによ り形成・維持される. 極性化させた単層上皮細胞層 に CagA タンパク質を発現させると, タイトジャン クションならびに頂端側-基底側極性が破壊され， CagA 陽性細胞は極性化細胞層から離脱する（図 6) ${ }^{21)}$ 。この活性は CagA のチロシンリン酸化には依 存しない。整然と整列すべき粘膜上皮から細胞が脱 落することにより粘膜構築は破壊される。粘膜破壊 が局所的に集中すると広範な粘膜障害に進展する. したがって，CagAによる細胞の極性破壊は胃炎・ 消化性潰瘍といった病態を引き起こす重要なメカ二 ズムのひとつと考えられる.

一連の CagA 変異体発現実験から, タイトジャン クションの破壊には CagA のアミノ酸配列中 1009 残基〜1086 残基が必要であることが明らかになっ た。 LC/MS/MS 質量分析法を用いてこの CagA 領域に特異的に結合する細胞タンパクを検索した 結果, PAR1b (partitioning-defective 1b) /MARK2 (microtubule affinity-regulating kinase 2) セリン/ スレオニンキナーゼが同定された（図 7 ${ }^{22)}$. CagA はチロシンリン酸化非依存的に PAR1b キナーゼド メイン内の 27 アミノ酸（250-276）に結合する.

PAR1b は上皮細胞の極性維持をつかさどる分子と して知られている ${ }^{23)}$. CagA との複合体形成の結果, PAR1bのキナーゼ活性は抑制され, タイトジャン クションならびに細胞極性の破壊が誘導される.

\section{CagA-PAR1-SHP-2 複合体形成とその意義}

PAR1 との結合には, CagA の EPIYA 領域内に 存在する 16 個のアミノ酸からなる配列が使われ る22).この配列は CagA が細胞内で多量体（おそら く二量体）を形成するために必要な領域として既に 同定されていた CM (CagA-multimerization) 配列 々一致する ${ }^{24)}$. CagA の多量体化 (二量体化) は CagA と SHP-2 の安定的な複合体形成ならびにそ れに引き続く SHP-2 の活性化に重要な役割を担 う. その後の研究から, PAR1b は細胞内で二量体
（ダイマー）として存在することが示され，2 分子 の CagA が CM 配列を介して PAR1b ダイマーに結 合する結果, CagAの二量体化が誘導されると考え られている22). PAR1bを介した CagAの二量体化 は, その後のチロシンリン酸化依存的な CagASHP-2 複合体形成に重要な役割を担う（図 8).さ らに興味深い事に, CagA-SHP-2 複合体形成を介 するハミングバード表現型の誘導には, CagA によ る PAR1b キナーゼの抑制が同時に必要であること も明らかとなった。従って, CagA-PAR-1b 複合体 は上皮細胞の極性破壊のみならず，その後の CagA-PAR-1b-SHP-2 複合体形成によるチロシン リン酸化依存的な $\mathrm{CagA}$ 活性にも重要な役割を担う ものと考えられる。

\section{VI. 生体内における CagA の発癌活性}

果たして CagA はそれ自身で細胞を癌化させる能 力を保有する癌タンパク質なのか, それとも細胞癌 化のプロセスを間接的に促進するだけの役割しか持 たないのであろうか.これまでの研究からはこの問 題に対する直接的な解答は得られていなかった。 ピ ロリ菌はマウスでは基本的に持続感染が成立しな い。一方, スナネズミを用いたピロリ菌感染実験で は胃癌発症が報告されているが，その発症率は極め て低く十分な再現性が得られていない.

こうした問題点を克服するとともにin vivoにお ける CagA の発癌活性を検証するため, CagA タン パク質を全身性に発現する $c a g A$ 遺伝子トランスジ エニック $(c a g A-\mathrm{Tg})$ マウスが作製された ${ }^{25)}$ 。得ら れた $\operatorname{cag} A-\mathrm{Tg}$ では, 生後 12 週までに約半数に上皮 細胞の過増殖にともなう胃壁の肥厚が認められ, 生 後 72 週までに一部のマウスから胃癌, 小腸癌が発 症した.さらに, $\operatorname{cag} A-\mathrm{Tg}$ マウスでは中等度の顆 粒球増多症が認められ, 一部のマウスでは生後 72 週までに骨髄性白血病ならびに B 細胞リンパ腫が 発症した。この結果から, CagA はマウス生体にお いて単独で癌を誘導できることが証明された。一 方, チロシンリン酸化されない変異型 $\mathrm{CagA}$ を発現 するトランスジェニックマウスでは腫瘍発生などの 異常は認められず, 細胞癌化にはチロシンリン酸化 非依存的 CagA 活性に加え, チロシンリン酸化依存 的活性が必要であることが示唆された。なお， $\operatorname{cag} A-\mathrm{Tg}$ マウスに認められる血液系悪性腫瘍のレ パートリーは, SHP-2 変異により引き起こされる ヒト血液癌のレパートリーと一致する。この結果か 
A

B

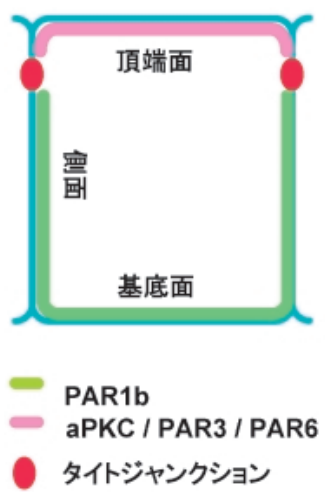

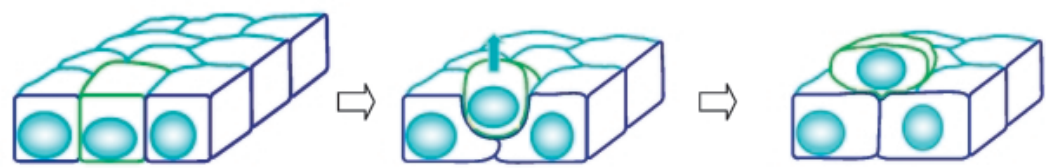

図 6 CagA による上皮細胞極性破壊

上皮細胞の頂端側-側基底側極性は，PAR1b とaPKC/PAR3/PAR6 という2つのキナーゼ（複合体）の非対称性分布により形 成・維持される (左図)。極性化された一層の上皮細胞層に CagA を発現させると, CagA 発現細胞（緑）はタイトジャンクショ ンを失い極性細胞層から離脱する（右図）。

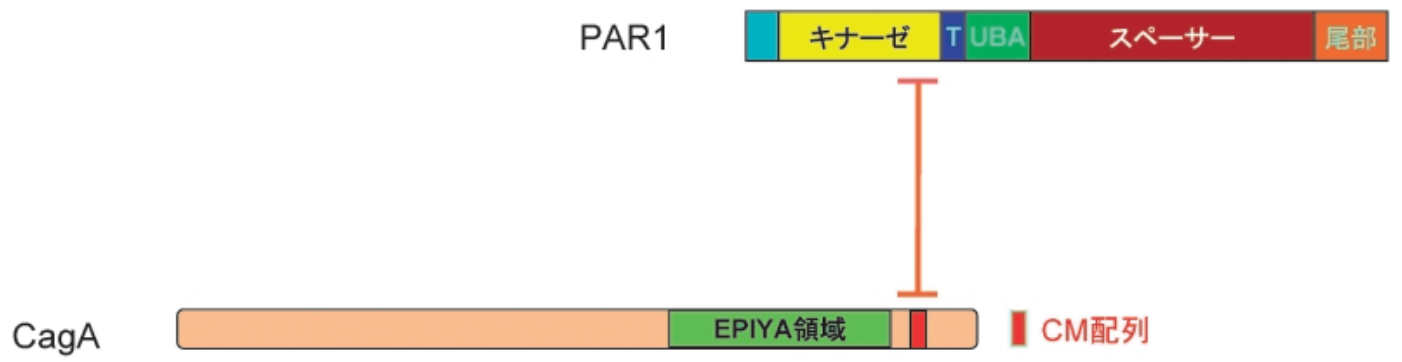

図 7 CagA-PAR1b 相互作用

CagA は自らの二量体化に必要な 16 個のアミノ酸配列（CagA-multimerization sequence : CM 配列）を介して PAR1b と結合 する。一方，PAR1b はセリン・スレオニンキナーゼドメインの C 末部位を構成する 27 個のアミノ酸配列を介して CagA と結合 する. CagA との複合体形成により, PAR1bのキナーゼ活性は抑制される.

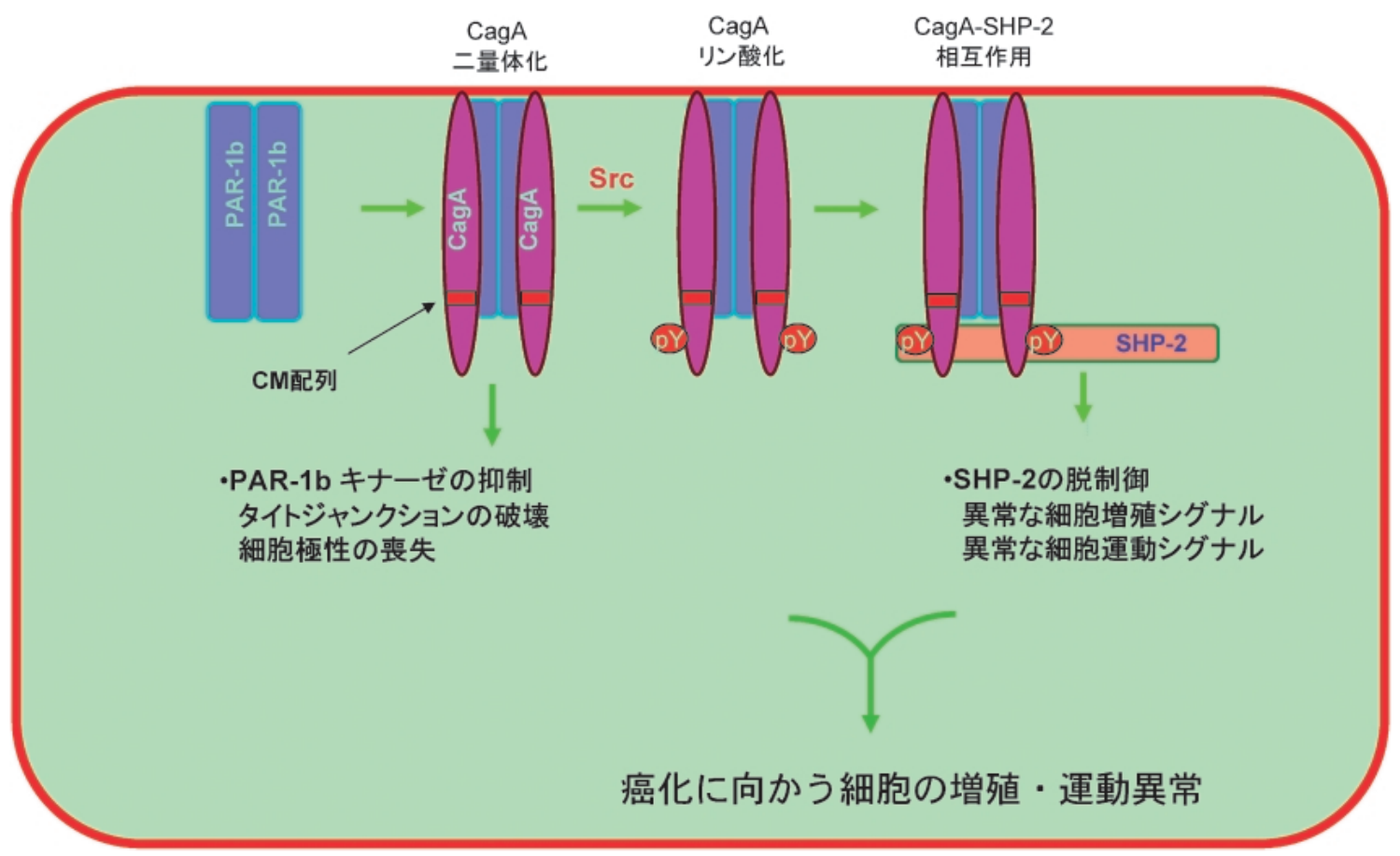

図 8 CagA-PAR1b-SHP-2 漸次複合体形成モデル

細胞内に侵入した CagA は CM 配列を介してPAR1b ダイマーと結合することにより間接的に二量体化する．CagA-PAR1b 複 合体形成の結果 PAR1b のキナーゼ活性は抑制され，タイトジャンクションならびに上皮細胞極性が破壊される. PAR1bにより 二量体化された CagA は Srcによるチロシンリン酸化を受け，SHP-2 が保有する 2 つ SH2 ドメインと安定的に結合する. CagA により脱制御された SHP-2 は異常な増殖・運動シグナルを生成する. CagA を介したこれら一連の細胞内シグナル系の擋 乱・破綻が発癌プロセスの進行に重要な役割を担うものと考えられる. 
ら，ピロリ菌 CagA は哺乳動物細胞の癌化を誘導す る細菌由来の初の癌タンパク質であることが個体レ ベルで明らかにされた。

\section{おわりに}

細胞癌化は複数個の癌遺伝子, 癌抑制遺伝子の質 的，量的発現異常を必要とする多段階のプロセスと 考えられ，この過程遂行には通常数十年を要すると 推察されている.ショウジョウバエの $l g l, d l g$, scribble などに代表される癌抑制遺伝子研究から, 整然と極性化された上皮細胞では, 隣接しあう細胞 が互いに癌化につながる異常な細胞増殖を抑制する システムが存在し，極性喪失が癌化シグナルに対す る細胞の感受性を増大させることが推察されてい る26). よって, CagA-PAR1 相互作用の結果として 正常な細胞間相互作用ならびに細胞極性を失った胃 上皮細胞が，CagA-PAR1-SHP-2 複合体形成によ り脱制御された SHP-2 が生成する増殖・運動シグ ナルを受けて細胞癌化につながる異常な細胞回転を 惹起するものと推察される。CagA 侵入にともなう 胃上皮細胞機能の擋乱と破綻は胃粘膜傷害を引き起 こすばかりでなく, 胃の多段階発癌プロセス促進に 重要な意義を担うことになろう.

我が国を含む東アジア諸国で胃癌が多発する原因 のひとつとして，より生物活性の強い CagA を保有 するピロリ菌の瞢延が示唆される，同様に，欧米諸 国に蔓延するピロリ菌 CagA 分子間では EPIYA-C サイト数のより多いものほど生物活性が強く, 重大 な疾病により深く関わる可能性が示唆される。この 可能性は, 胃癌患者 6 名のうち 5 名が 2 個以上の EPIYA-C サイトを保有していた一方，非癌患者 18 名のう 17 名は EPIYA-C サイトを 1 つしか持たな かった ${ }^{27)}$, という最近の報告からも支持される.

細菌タンパクの宿主細胞内への移行という現象 は, 細菌感染症に打ける細菌一宿主相互作用理解に 新展開を与えるものである.ピロリ菌 CagA は細菌 発癌 (bacterial carcinogenesis), 細菌性癌タンパク (bacterial oncoprotein) という癌研究の新たなパラ ダイムを生んだ。ピロリ菌による発癌機構の解明 は, 単に胃癌の理解に留まらず肝細胞癌, 子宮䅡 癌, 成人 $\mathrm{T}$ 細胞白血病々いった慢性感染症を基盤 とする癌, さらには胸膜中皮腫や肺癌など慢性・持 続性炎症を原因とする癌の発症機構理解に役立つこ とが強く期待される.

\section{文献}

1) Guilford P, Hopkins J, Harraway J, et al. : Ecadherin germline mutations in familial gastric cancer. Nature 392 : 402-405, 1998.

2) Uemura $N$, Okamoto $S$, Yamamoto $S$, et al. : Helicobacter pylori infection and the development of gastric cancer. $N$ Engl J Med. 345 : 784-789, 2001.

3) Du MQ, Isaccson PG.: Gastric MALT lymphoma : from aetiology to treatment. Lancet Oncol. 3 : 97-104 : 2002.

4) Marshall BJ, Warren JR : Unidentified curved bacilli in the stomach of patients with gastritis and peptic ulceration. Lancet $1: 1311-1315$, 1984.

5) Covacci A, Censini S, Bugnoli $M$, et al. : Molecular characterization of the $128-\mathrm{kDa}$ immunodominant antigen of Helicobacter pylori associated with cytotoxicity and duodenal ulcer. Proc Natl Acad Sci USA. 90 : 5791-5795, 1993.

6) Censini $\mathrm{S}$, Lange $\mathrm{C}$, Xiang $\mathrm{Z}$, et al. : cag, a pathogenicity island of Helicobacter pylori, encodes type I-specific and disease-associated virulence factors. Proc Natl Acad Sci USA. 93 : 14648-14653, 1996.

7) Blaser MJ, Perez-Perez GI, Kleanthous H, et al. : Infection with Helicobacter pylori strains possessing $\operatorname{cag} A$ is associated with an increased risk of developing adenocarcinoma of the stomach. Cancer Res. 55 : 2111-2115, 1995.

8) Kuipers EJ, Perez-Perez GI, Meuwissen SG, et al. : Helicobacter pylori and atrophic gastritis : importance of the $\operatorname{cag} A$ status. $J$ Natl Cancer Inst. 87 : 1777-1780, 1995.

9) Segal ED, Cha J, Lo J, et al. : Altered states : Involvement of phosphorylated $\mathrm{CagA}$ in the induction of host cellular growth changes by Helicobacter pylori. Proc Natl Acad Sci USA. 96 : 14559-14564, 1999.

10) Higashi H, Tsutsumi R, Muto S, et al. : SHP-2 tyrosine phosphatase as an intracellular target of Helicobacter pylori CagA protein. Science 295 : 683-686, 2002.

11) Stein $\mathrm{M}$, Bagnoli $F$, Halenbeck R, et al. : $\mathrm{c}-\mathrm{Src} /$ Lyn kinases activate Helicobacter pylori CagA through tyrosine phosphoryulation of the EPIYA motifs. Mol Microbiol. 43 : 971-980, 2002.

12) Higashi H, Tsutsumi R, Fujita A, et al. : Biological activity of the Helicobacter pylori viru- 
lence factor CagA is determined by variation in the tyrosine phosphorylation sites. Proc Natl Acad Sci USA. 99 : 14428-14433, 2002.

13) Higashi H, Yokoyama K, Fujii Y, et al. : EPIYA motif is a membrane targeting signal of Helicobacter pylori virulence factor CagA in mammalian cells. J Biol Chem. 280 : 2313023137, 2005.

14) Naito M, Yamazaki T, Tsutsumi R, et al. : Influence of EPIYA-repeat polymorphism on the phosphorylation-dependent biological activity of Helicobacter pylori CagA. Gastroenterology 130 : 1181-1190, 2006.

15) Tsutsumi R, Takahashi A, Azuma T, et al. : FAK is a substrate and downstream effector of SHP-2 complexed with Helicobacter pylori CagA. Mol Cell Biol. 26 : 261-276, 2006.

16) Higashi $\mathrm{H}$ et al : Helicobacter pylori CagA provokes Ras-independent morphogenetic response through SHP-2 recruitment and activation. $J$ Biol Chem. 279 : 17205-17216, 2004.

17) Neel BG, Gu H, Pao L. : The 'Shp'ing news : $\mathrm{SH} 2$ domain-containing tyrosine phosphatase in cell signaling. Trends Biochem Sci. 28 : 284293, 2003.

18) Tartaglia M, Mehler EL, Goldberg R, et al. : Mutations in PTPN11, encoding the protein tyrosine phosphatase SHP-2, cause Noonan syndrome. Nat Genet. 29 : 465-468, 2001.

19) Tartaglia M, Niemeyer CM, Fragale A, et al. : Somatic mutations in PTPN11 in juvenile myelomonocytic leukemia, myelodysplastic syndromes and acute myeloid leukemia. Nat Genet. 34 : 148-150, 2003.
20) Bentires-Alj M, Paez JG, David FS, et al. : Activating mutations of the noonan syndromeassociated SHP2/PTPN11 gene in human solid tumors and adult acute myelogenous leukemia. Cancer Res. 64 : 8816-8820, 2004.

21) Amieva MR, Vogelmann R, Covacci A, et al. : Disruption of the epithelial apical-junctional complex by Helicobacter pylori CagA. Science 300 : 1430-1434, 2003.

22) Saadat I, Higashi H, Obuse C, et al. : Helicobacter pylori CagA targets PAR1/ MARK kinase to disrupt epithelial cell polarity. Nature 447 : 330-333, 2007.

23) Suzuki A, Ohno S: The PAR-aPKC system : lessons in polarity. J Cell Sci. 119 : 979-987, 2006.

24) Ren S, Higashi H, Lu H, et al. : Structural basis and functional consequence of Helicobacter pylori CagA multimerization in Cells. J Biol Chem. 281 : 32344-32352, 2006.

25) Ohnishi N, Yuasa H, Tanaka S, et al. : Transgenic expression of Helicobacter pylori CagA induces gastrointestinal and hematopoietic neoplasms in mouse. Proc Natl Acad Sci USA. 105 : 1003-1008, 2008.

26) Bilder D : Epithelial polarity and proliferation control : links from the Drosophila neoplastic suppressors. Genes Dev. 18 : 1909-1925, 2004.

27) Argent RH, Kidd M, Owen RJ, et al. : Determinants and consequences of different levels of CagA phosphorylation for clinical isolates of Helicobacter pylori. Gastroenterology 127 : 669-672, 2004. 